\title{
EFFECTIVENESS OF DIAGNOSING DAMAGE TO AN INDUSTRIAL PUMP ROTOR BY ANALYSING ITS VIBRATIONS
}

\author{
Janusz ZACHWIEJA \\ University of Technology and Life Sciences in Bydgoszcz, Faculty of Mechanical Engineering, \\ Bydgoszcz janusz.zachwieja@utp.edu.pl
}

\begin{abstract}
The paper presents the issue of effectiveness of diagnosing imperfections of high performance industrial pumps. At present, the most commonly applied diagnostic method for such machines is based on an analysis of the rotor vibration spectrum. Measurements of vibrations over time are not often performed on a continuous basis, they are rather carried out periodically, according to a defined inspection schedule. The reliability of this diagnostic method is based on an assumption that damage to a rotor does not occur rapidly, but it is a process stretched over a longer period of time resulting in a change of rotor movement dynamics. The most frequently occurring type of pump rotor damage is a fatigue crack of a shaft, the propagation of which actually proceeds in a finite period of time. However, there is also damage caused by a rapid pump load increase leading to stresses in rotor or disc sections, which exceed permissible values resulting from mechanical properties of material used to manufacture the rotor. Some imperfections are not related to rotor damage but result from the nature of cooperation between the pump and a pipeline connected thereto.
\end{abstract}

Keywords: fatigue crack, resonance frequencies, pipeline vibrations, self-organisation systems, VSD technique

\section{SKUTECZNOŚĆ DIAGNOZOWANIA USZKODZENIA WIRNIKA POMPY PRZEMYSŁOWEJ METODĄ ANALIZY JEGO DRGAŃ}

\section{Streszczenie}

W pracy omówiono problematykę skuteczności diagnozowania imperfekcji pomp przemysłowych o dużej wydajności. Obecnie najczęściej spotykana metoda diagnozowania tych maszyn jest oparta na analizie widma drgań wirnika. Pomiary przebiegów czasowych drgań są wykonywane rzadziej w sposób ciągły, częściej okresowo, według przyjętego harmonogramu przeglądów. Wiarygodność tego sposobu diagnozowania oparta jest na założeniu, że uszkodzenie wirnika nie wystąpi nagle, lecz jest procesem rozciągniętym w czasie i ma wpływ na zmianę dynamiki ruchu wirnika. Najczęstszym rodzajem uszkodzenia wirnika pompy jest pęknięcie zmęczeniowe wału, którego propagacja rzeczywiście przebiega w skończonym przedziale czasu. Zdarzają się jednak również uszkodzenia spowodowane nagłym wzrostem obciążenia pompy powodującym powstanie $\mathrm{w}$ przekrojach wału lub tarczy naprężeń przekraczających wartości dopuszczalne wynikające $\mathrm{z}$ własności mechanicznych materiału użytego do wytworzenia wirnika. Niektóre imperfekcje nie są związane z uszkodzeniem wirnika lecz wynikają z charakteru współpracy pompy z połączonym z nią rurociągiem.

Słowa kluczowe: pęknięcie zmęczeniowe, częstości rezonansowe, drgania rurociągu, układy samorganizacji, technika VSD.

\section{WSTEP}

The purpose of diagnosing machines is to determine their degree of fitness. Since it is usually performed on a machine in operation, it provides information on its dynamic condition. Diagnostic systems are designed to define - in due advance the risk of damage to the machine, rendering it unsuitable for operation.

The development process of damage is usually stretched over a period of time, therefore it is possible to analyse trends in changes of operational parameters affecting the life cycle of machine components. A carrier of such information is a signal received from vibration parameter measurements. It is not, however, information allowing for precise determination of the source of an imperfection, since a given vibration spectrum signal component is often a symptom of various damage.

Industrial pumps play a crucial role in many production processes. Their structure is not complex. Thus, one could expect that diagnosing their condition should not be a complex process, as only the shaft, the rotor disc and the bearings are subjected to loads.

Although modern rotor shaft structures allow for transmission of heavy fatigue loads owing to top quality materials and technologies used to manufacture them, failures of fluid-flow machines occur often. Reasons for the above, besides damage to bearings which is a natural process, include cracking of the rotor disc and the shaft. This happens especially to rotors reaching high rotating speed in 
operation. Therefore, it becomes significantly important to apply machine dynamic condition diagnostic methods so their possible damage is detected at the stage of emergence and early development. Many tests concentrate on analysing models of the rotor and its reaction under cracking conditions using theoretical methods, whereas other combine both approaches: theoretical and experimental.

Hamidi, Piaud and Massoud [1] have developed two mathematical models to determine natural frequency of the rotor using the stress intensity factor in the crack area. Results of the theoretical analysis have been compared to measurement results, and this allowed them to draw conclusions that at crack depth higher than $30 \%$ of the shaft radius the speed of natural frequency variations is very high and the rotating speed of the shaft has no influence on the value of natural frequency.

Sinou and Lees [2] have analysed a reaction of the rotating shaft in order to predict the influence of a transverse crack on its dynamics. They have also tested a change of the shape of the rotor shaft orbit with a crack at speed equalling half and one third of the first critical speed. They used the harmonic balance method to determine the nature of rotor reactions for different crack depth and locations.

Li et al. [3] have run a FEM-based simulation for modelling dynamic characteristics of a multi-body rotor with cracks located in different points. Individual parts of the rotor were connected to each other with diaphragm couplings. This allowed them to analyse the coupling of torsional and bending vibrations of the rotor. The tests were conducted for three crack depth values with the following dimensions: $20 \%, 40 \%$ and $60 \%$ of the shaft diameter. On the basis of the said analyses, they came to a conclusion that a change of critical speed of the shaft is considerably affected at higher crack depth values only.

Saravanan and Sekhar [4] have applied experimental and analytical bearing-rotor unit monitoring procedures to test the presence of transverse cracks. The shaft was supported on two rolling bearings and the disc was mounted at the centre of the shaft. Initially, a gap was positioned in the middle of the shaft, then close to the bearing. The authors stated that the influence of a crack on the change of shaft dynamics was significant for a crack located next to the bearing. This influence decreased when the crack was moved closer to the centre of the shaft.

Huang et al. [5] have tested a dynamic response of a rotor model with a transverse crack, formulating equations of rotor movement and then solving them numerically. They have tested frequency characteristics of a model of a shaft of different depth and locations of cracks, showing that in each case the rotor response spectrum contains high value amplitudes for harmonics of $1 \mathrm{x}$ and $2 \mathrm{x}$.

Luo et al. [6] have created a dynamic model of a bearing-mounted rotor with crack-type damage and contact rotor-to-stator rubbing. The results indicate that there is unique dynamic characteristics of the bearing-rotor unit with cracks, in combination with rotor rubbing. It differs from characteristics typical for single imperfections.

Zheng has analysed vibrations of rotors with cracks using the numerical method [7]. In his opinion, the growth of harmonic components other than $1 \mathrm{x}$ and $2 \mathrm{x}$ also indicates possible rotor cracks. Wen et al. [8] have tested dynamic characteristics of an unbalanced rotor with a crack, being in contact with the stator on a periodic basis. Wan [9] has carried out similar analyses using the harmonic wavelet transform (HWT). Darpe [10] has presented a new method of detecting a transverse fatigue crack of spinning rotors. He has applied the wavelet analysis method to show the transitional character of resonance vibrations excited by short-term torsional vibrations.

Dimarogonas and Paipetis [11] have expanded the relationship between the depth of cracks and local flexibility of a rotor. Loya et al. [12] proposed a method of modelling stiffness of the Timoshenko beam in the crack point by using two springs torsional and longitudinal. The results obtained were identical to those received when applying numerical methods.

The presented review of selected literature indicates that the issue of vibrations of a rotor with cracks was a subject of many analyses, the results of which were not always consistent. It is commonly believed that growth of $2 \mathrm{x}$ and $3 \mathrm{x}$ ultra-harmonics of the rotational frequency of the rotor and reduction of the frequency of its free vibrations to lower values are symptoms of the occurrence of a crack. Such conclusions were made mainly on the basis of solved equations written for specific rotor models. Rotors of machines in which a crack occurred and developed were tested less often.

The subject of the research in this paper is an attempt of defining the possibility of observing symptoms of imperfections and determining reasons of the same, using commonly applied diagnostic methods which involve measurements of vibration parameters and interpretation of the nature of their spectrum.

\section{DIAGNOSING CONDITION OF A PUMP WITH AN IMPERFECTION STRETCHED OVER A PERIOD OF TIME}

Due to its design, a pump is a simple fluid-flow machine. Usually, in order to diagnose it, it is sufficient to measure and analyse parameters of bearing vibrations to determine the degree of their wear and tear and the concentricity of the pump rotor shafts and the engine. This scope of diagnosis is a standard test for many machines and has been discussed in detail in relevant literature.

A pump cannot be treated as an autonomic unit, but rather as a system it forms with a pipeline. Thus, there is a mutual coupling between vibrations of the 
pump and the pipeline, in particular when no compensator is used in the system between the pump connectors and the pipeline.

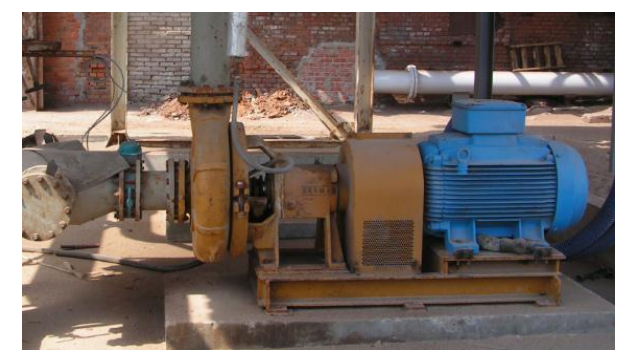

Fig. 1. A view of a Worman pump connected to a pipeline

Fig. 1 presents a Worman pump connected to pipelines. Measurements of vibrations conducted for diagnostic purposes have indicated the presence of high values of vibration parameter amplitudes, both of the pump and the pumping pipeline connected thereto. This condition often makes the pipeline connector crack, causing destabilisation of the production process and posing a threat to the environment.

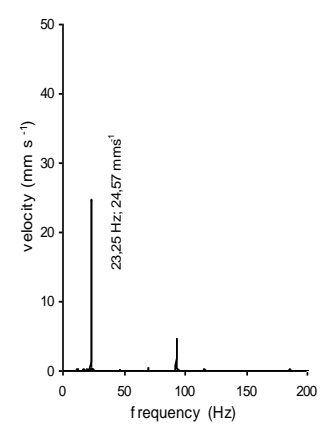

A

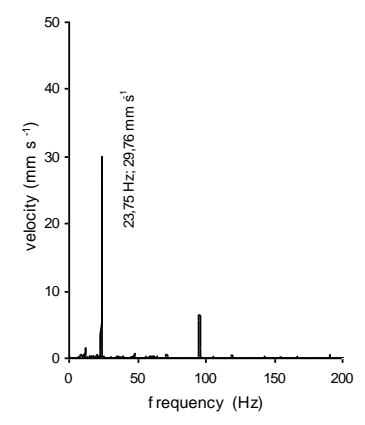

B
Fig. 2. A spectrum of the velocity of vibrations in a horizontal direction of the pump bearing

(A) and the pipeline connector (B)

A comparison of amplitude values of pump and pipeline vibration velocities for $\mathrm{f}=23.75 \mathrm{~Hz}$ (Fig. 2) pump operating frequency allows us to come to a conclusion that these vibrations are coupled. To determine resonance frequency of the pipeline, it was excited with an inductor mounted on the pipeline perpendicularly to its axis.

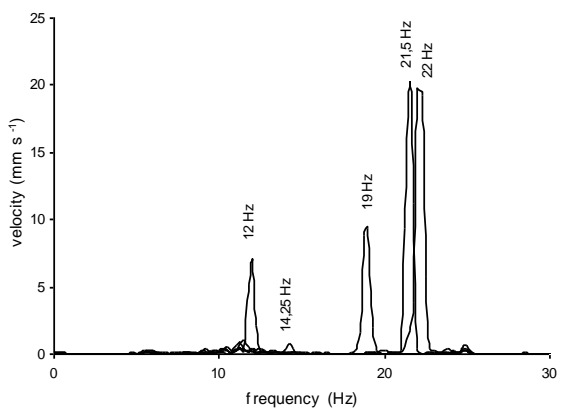

Fig. 3. A spectrum of the velocity of vibrations of pipeline responses to excitation of $12 \mathrm{~Hz}$, 14.25 Hz, $19 \mathrm{~Hz}, 21.5 \mathrm{~Hz}$ and $22 \mathrm{~Hz}$ frequency.
The excitation frequency was $12 \mathrm{~Hz}, 14.25 \mathrm{~Hz}, 19$ $\mathrm{Hz}, 21.5 \mathrm{~Hz}, 22 \mathrm{~Hz}$. Responses of the pipeline are presented in Fig. 3.

The results of the test explain the pipeline vibration amplitude growth mechanism for rotating speed of the pump $\left(\sim 1440 \mathrm{rpm}^{-1}\right)$. At the frequency of $12 \mathrm{~Hz}$, a significant growth of the level of vibrations can be observed due to the fact that this frequency is a $0.5 \mathrm{x}$ subharmonic of the rotational frequency of the rotor. An increase of the excitation frequency causes a rapid decrease of the vibration level. At the frequency of $14 \mathrm{~Hz}$, the vibration velocity amplitude is $0.81 \mathrm{~mm} \mathrm{~s}^{-1}$. A further growth of the excitation frequency results in an increase of the vibration velocity amplitude. Taking the relation:

$$
\frac{A(f=21.5 H z)}{A(f=19 H z)}=2.17
$$

and whereas:

$$
\frac{f^{2}(21.5 H z)}{f^{2}(19 H z)}=1.28
$$

it means that the amplitude increase is not caused by a change of the excitation value, but it is of a resonance nature.

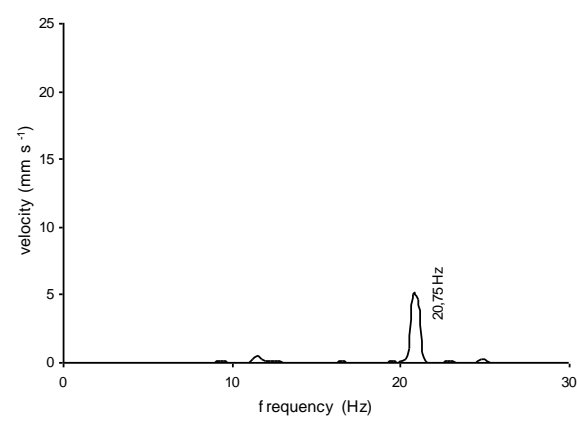

Fig. 4. An amplitude and frequency spectrum of the velocity of vibrations at the excitation frequency of $20.75 \mathrm{~Hz}$

Decreasing the rotating speed of the rotor to $1245 \mathrm{rpm}^{-1}$ makes a four-fold reduction of vibration velocity amplitude values (Fig. 4).

This example shows that diagnosing dynamic condition of a pump only by monitoring its vibrations allows us to observe the presence of a phenomenon which has a negative effect on the durability of the pump-pipeline system. It is not, however, sufficient to assess the nature of this phenomenon. Without additional tests, removal of the reason for an imperfection is not possible.

\section{DIAGNOSING CONDITION OF A PUMP WITH A SHORT-TERM IMPERFECTION}

A short-term imperfection is a common reason for unfitness of a pump. Unlike fatigue damage, which develops over time in the form of a crack, instantaneous damage occurs in the event of a 
temporary increase of a stress in shaft or rotor disc sections above a permissible value.

An example of damage of this type is a crack of a rotor shaft of a large industrial pump. The shaft got twisted (Fig. 5) in a section located close to the bearing on the side opposite to the drive. This occurred two months after the bearings had been replaced. Renovation of the pump was imposed by the observed increase of the rotor vibration parameter amplitude of an unknown reason.
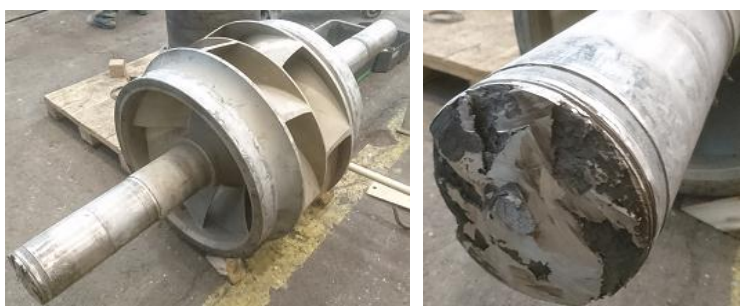

Fig. 5. A view of the rotor and section in the crack area

A pump is a double-suction fluid-flow machine. Vibration velocity spectra measured before replacement of the bearings, following one year of operation, are given in Fig. 6.

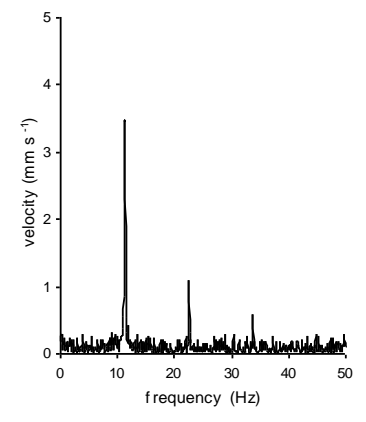

A

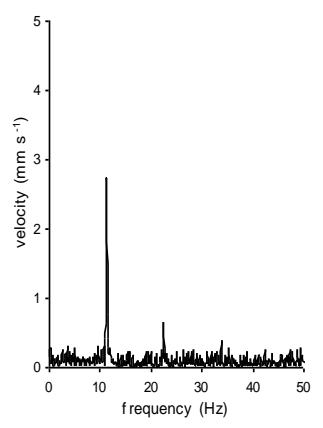

B
Fig. 6. A spectrum of the velocity of vibrations in a horizontal direction of unfit rotor bearings: (A) on the side opposite to the drive, (B) on the drive side

The nature of the vibration velocity spectrum shows play in the bearings. On this basis, the bearings were qualified for replacement.

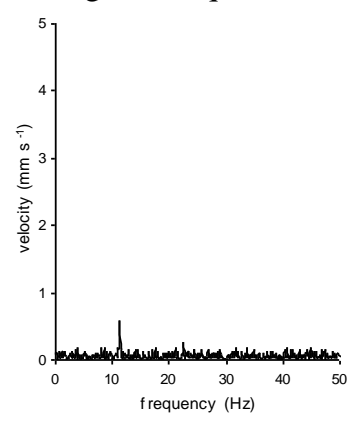

A

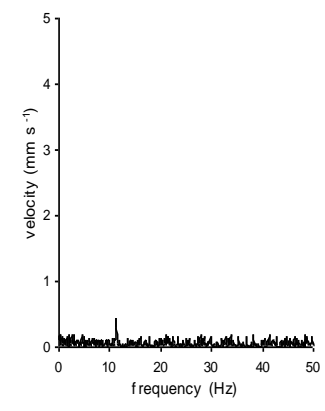

B
Fig. 7. A spectrum of the velocity of vibrations in a horizontal direction of fit rotor bearings: on the side opposite to the drive (A) and on the drive side (B).
After replacement of the bearings, amplitudes of rotor vibration velocities for the rotational frequency and $2 \mathrm{x}$ and $3 \mathrm{x}$ ultra-harmonics decreased, which excludes the observed symptoms as a consequence of the existence of a shaft crack (Fig. 7).

Components of the rotor, according to manufacturer's information, are made of Duplex steel (1.4462 as per EN). It is steel of very good anticorrosion and strength properties. However, it is not resistant to high temperatures. Duplex steel can be freely used at operating temperatures ranging from $-50^{\circ} \mathrm{C}$ to $250^{\circ} \mathrm{C}$, since it loses its strength properties above this limit, becoming a brittle material. In comparison to classic austenitic steels it shows much higher tensile strength at the recommended temperature. The basic fault of Duplex-type steels is their tendency of precipitation of brittle phases at raised temperatures. Precipitation of such phases deteriorates corrosion resistance and reduces plastic properties of steels.

Tensile strength of Duplex steel (austeniticferritic steel) is usually two times higher than yield point, whereas for austenitic steels this relation is barely approx. 0.35 . This comparison is in favour of Duplex steel, since - due to structural reasons - the basic value defining suitability of a given steel grade is its yield point. When handling components made of Duplex steel at raised temperatures, it should be taken into account that yield point may decrease due to an impaired reinforcing effect of nitrogen. This occurs because nitrogen atoms dissolved in austenite become more movable, so they can block dislocation motion to a lesser extent.

Metallographic examination of the fracture was carried out to determine the crack nature.

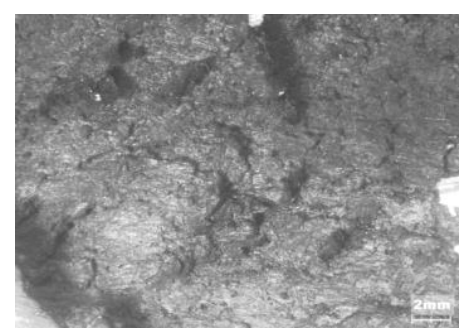

Fig. 8. A fracture metallographic image

A macroscopic image of the fracture (Fig. 8) with a distinct feature of a brittle fracture and secondary cracks indicates an instantaneous, not fatigue nature of the rotor shaft damage.

The performed strength analysis of the rotor for a load equalling a maximum torque has demonstrated a significant influence of the rotor inertia on its durability.

During operation, at a maximum load of the rotor, stresses in shaft sections do not exceed 60 $\mathrm{MPa}$. Thus, there is no risk that possible damage could be fatigue (Fig. 9). This is not the case when the rotor stops suddenly due to damage to the bearing. If the rotor stoppage time is $0.5 \mathrm{~s}$, stresses in shaft sections reach $\sim 250 \mathrm{MPa}$. The condition of 
components of the broken bearing indicate that its temperature reached $600^{\circ} \mathrm{C}-650^{\circ} \mathrm{C}$, at which point there was a rapid decrease of yield and breaking points of Duplex steel. That is why damage to the shaft occurred in the bearing seat point on the side opposite to the drive, not next to the coupling.

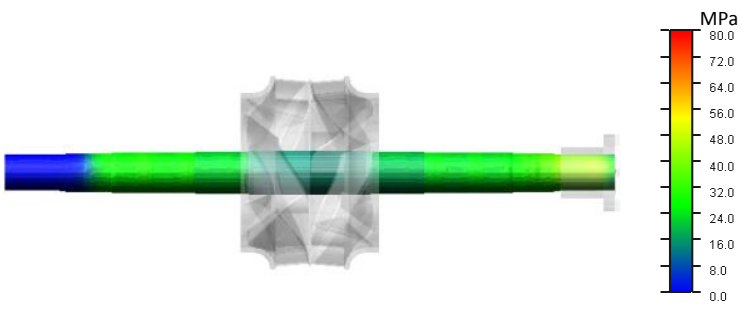

Fig. 9. Distribution of stresses in sections of a shaft loaded by a maximum torque ( 15280 $\mathrm{Nm})$

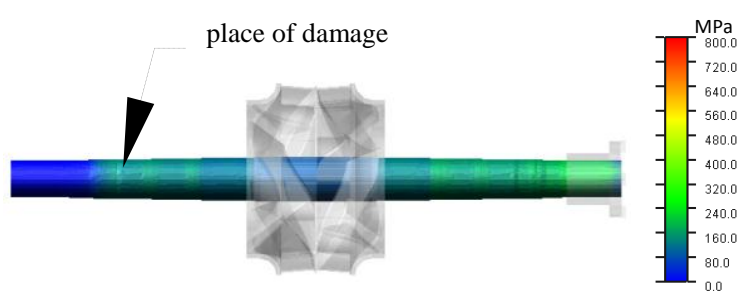

Fig. 10. Distribution of stresses in sections of a shaft loaded by a maximum torque $(15280$

$\mathrm{Nm})$ at a rapid stoppage of the rotor

Dynamic condition of the pump rotor is not diagnosed on a continuous basis. Damage to the rotor occurred in a short time, therefore, even if the pump had been equipped with a vibration diagnostic system, the damage could not have been identified. However, the question is 'Is this type of diagnosis capable of indicating the beginning and development of a crack?' As the failure and damage to the rotor became a fact, an analysis of dynamic condition of the rotor with a crack can be carried out only on the basis of a numerical model.

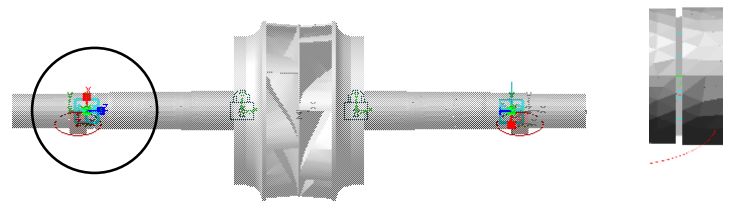

Fig. 11. A view of the rotor and section in the crack area

The problem is that stiffness of the rotor, its attenuation, as well as stiffness and attention of the pump body are unknown. The rotor unbalance value is not defined either. A possible comparison of responses of a rotor with and without a crack can be reliable only after estimating the above-mentioned values. Therefore, an assumption was made that the rotor is isotropic and seated on bearings which are mounted in a high stiffness body.

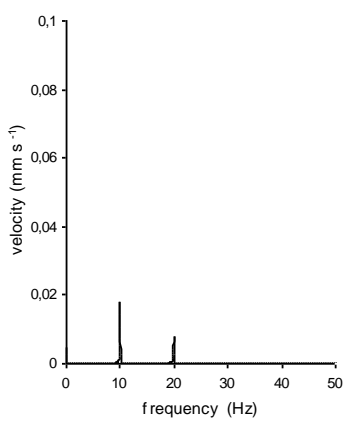

A

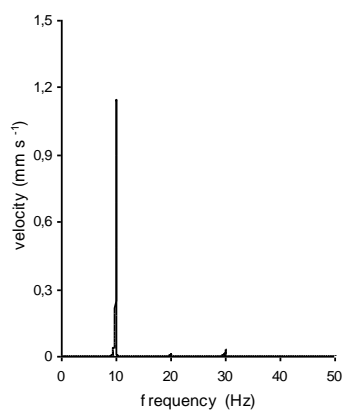

B
Fig. 12. A spectrum of the velocity of vibrations of a rotor without a crack in an axial (A) and vertical (B) direction.

Despite many uncertainties, the analysis performed can be considered reliable, since material features and the shaft geometry are known. A change of the shaft strength and stiffness does not depend on physical features of other rotor components. A $0.75 \mathrm{D}$ (D - shaft diameter) deep crack was assumed in the form of a regular gap (Fig. 11).

As the number of researchers [1-7] focused on determination of the effect of a crack on relations between $1 \mathrm{x}$ and $2 \mathrm{x}$ harmonics of excitation, this indicator was applied to identify the presence of discontinuities. Fig. 12 presents the amplitudefrequency characteristics of the velocity of shaft vibrations in axial direction and vertical directions.

A spectrum of vibrations in an axial direction contain low value amplitudes for $1 \mathrm{x}$ and $2 \mathrm{x}$ frequencies. A spectrum of vibrations in a vertical direction contains a dominant signal components of $1 \mathrm{x}$ frequency.

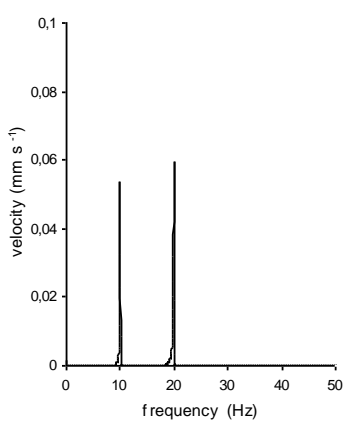

A

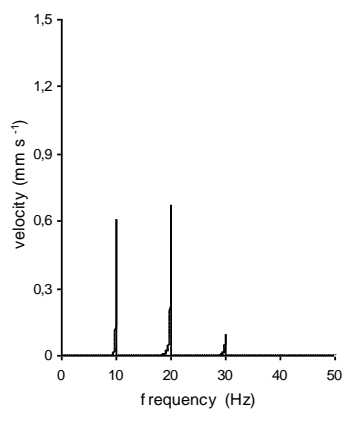

B
Fig. 13. A vibration velocity spectrum of a shaft with a crack in axial (A) and vertical (B) directions

The nature of responses of the cracked rotor is interesting. A spectrum of the velocity of vibrations in an axial direction also contains dominant amplitudes for $1 \mathrm{x}$ and $2 \mathrm{x}$ frequencies, whereas their values are higher than for a rotor without discontinuities. A spectrum of vibrations in a vertical direction now contains dominant amplitudes of signals of $1 \mathrm{x}, 2 \mathrm{x}$ and $3 \mathrm{x}$ frequencies (Fig.13). Their values are lower than that observed for a rotor 
without a crack. The following relation exists in this case:

$$
A(3 x<) A(1 x)<A(2 x)
$$

This characteristic shape of the spectrum may be deemed a symptom of crack development. Monitoring of vibration parameters and its analysis, regardless whether it is conducted continuously or on a periodic basis, may detect the progressing development of a crack. Of course, for fatigue damage, not instantaneous one.

\section{DIAGNOSING A PUMP ROTOR IN AN EMERGENCY CASE}

Rotor disc components come off very often in crushers, wood chipping machines, i.e. impact operation machines [13]. Tests of turbines demonstrated that in addition to resonance vibrations excited by variable loading conditions, a crack of the blade results from progressive corrosion [14], pitting [15] and an unbalanced rotor [16]. Rotating speed of turbine generators reach values of up to $10^{4} \mathrm{~min}^{-1}$. At large disc diameters, kineto-static loads stresses cause damage to the rotor.

For pumps, the reason for damage can be a reverse flow which occurs at a negative pressure gradient. In such a case, the pump rotor tends to rotate in a direction opposite to the drive torque affecting the same rotor. The rotor disc is twisted and pushed against the pump suction connector with a force resulting from the difference of pressure downstream and upstream the pump disc.

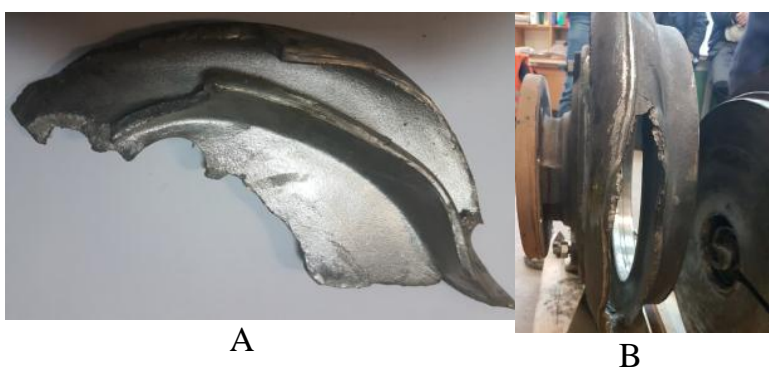

Fig. 14. A pump damage image: (A) disc fragment, (B) ruptured pump chamber

Fig. 14 shows the effect of an event involving a disc sliding out of the shaft seat, hitting the front part of the pump body and falling to pieces. Components rotating with fluid in the spiral chamber of the pump caused damage to the pump (Fig. 12B). The history plot of the disc coming off the shaft is shown in Fig. 15.

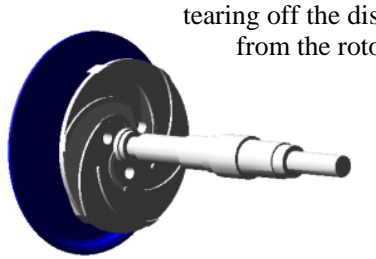

A

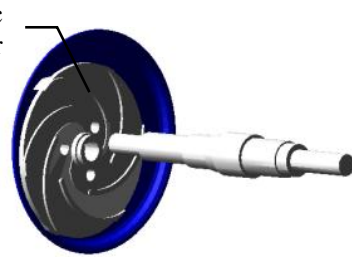

$\mathrm{B}$
Fig. 15. Phases: initial and final phases of the rotor disc hitting the pump chamber wall: $\mathrm{A}$ - the disc starts to slip off the shaft, B - the disc hits the pump body

A time-history plot of the vibration velocity shows an incremental growth of the signal amplitude at the point when the disc comes off the shaft and hits the pump body. The impact was that great, it made the pump shaft with the coupling move, despite movement being blocked by the engine. The spectrum of the velocity of vibrations informs about an increase of their amplitude for the 1x rotational frequency and the $2 \mathrm{x}$ ultra-harmonic frequency only (Fig. 16).

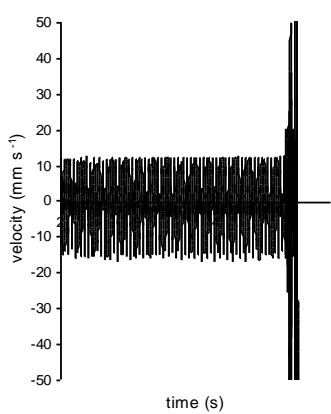

A

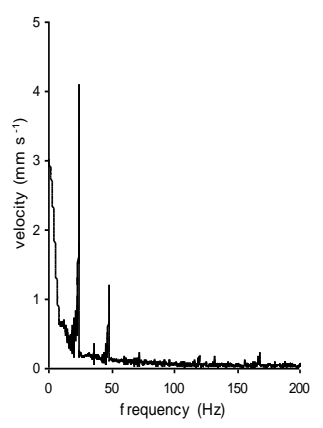

B
Fig. 16. (A) A time-history plot of the vibration velocity until the fall of the disc. (B) A spectrum of the velocity of vibrations of the pump bearing in the vicinity of the rotor disc

The system monitoring dynamic condition of the pump reacted properly by disconnecting power supply of the pump drive. Benefits of its existence are obvious. Although it did not prevent the failure, as the reason for the same was sudden and unforeseeable, it protected the system from higher degradation, i.e. from destruction of the coupling and twisting of the engine shaft.

\section{SUMMARY}

Excessive vibrations in a pump may result from its improper installation or maintenance, inappropriate selection of pipeline geometry or improper connection with the pump. Cavitation in the pump or pipeline may also cause pump vibrations.

In addition to costs of power and maintenance, losses caused by pump downtimes have a substantial influence on the general pump maintenance cost balance. Still, pump protection and diagnostic systems are not widely used. Such solutions require installation of sensors to acquire operating parameters and data processing units, which has a significant impact on implementation costs. Modern control systems are capable of changing rotating speed of a pump, thus adjusting its capacity to short-term needs. Speed control is ensured by the VSD (Variable Speed Drive) technique. The said systems allow for continuous monitoring and diagnostics of a machine with an advance diagnostic algorithm. It is based on acquisition of data and definition of pump operating parameters from an implemented pump model. Each 
pump manufacturer provides pomp characteristics showing the relation between their power and efficiency. The perfect operating point of the pump is the so-called Best Efficiency Point (BEP) in which efficiency and pressure guarantee conditions of optimal operation. The acoustic emission (AE) method applied in pump diagnostics is used to detect the cavitation phenomenon and control pump operation, in order to achieve the best efficiency.

When diagnosing dynamic condition of pumps, self-organising units (SOM - self organising map) are applied. The SOM-based approach allows for combination of symptoms of a few imperfections related to damage and its evolution.

Regardless of the complexity of units used to diagnose pumps, they hardly ever fulfil expectations for such devices. This results not only from their imperfection, although this is constantly improving, but also from the exploitation policy followed by companies focused on maximum profit. Obtaining information on damage, which does not entail rendering the pump unsuitable for operation immediately, does not mean that the machine has to be stopped. It is possible, when the system features alternative circulation. In many cases, exceeding warning and alarm thresholds cause their level to increase. As the presented examples show, monitoring systems are effective when pump damage develops over time. In emergency cases, they serve as a fuse protecting from damage to other pump components.

Diagnosing condition of a pump should not be limited to the implementation of a system monitoring pump condition in operation only. Even after occurrence of damage, the subsequent diagnosis stage should follow, i.e. determination of the failure source. In most cases, a material and strength analysis of a damaged component is sufficient to define the damage reason. Modelling of pomp operation and pipeline flow is important too. The wider scope of diagnostics applied, the more information concerning conditions in which damage can occur we are able to obtain. With this, such damage can be eliminated ad hoc or in the future.

\section{REFERENCES}

1. Hamidi L, Piaud J, Massoud M. A study of crack influence on the modal characteristics of rotors. International Conference on Vibrations in Rotating Machinery, held at Bath, UK, Paper C432/066, 1992, 283-288.

2. Sinou JJ, Lees AW. A Non-linear study of a cracked rotor. European Journal of Mechanics and Solids, 2007, 26, 152-170.

3. Li X, Yao H, Ren Z, Wen B. Simulation of dynamic characteristics of faulty multi-span rotor system through FEA. 15th International Congress on Sound and Vibration, Daejeon, Korea, 2008.

4. Saravanan K, Sekhar A. Crack detection in a rotor by operational deflection shape and kurtosis using laser vibrometer measurements. Journal of Vibration and Control, 2012, 19 (8), 1227-1239.

5. Huang SS, Wu MC. In-Plane vibration and crack detection of a rotating shaft disk containing a transverse crack. Journal of Vibration and Acoustics, 1998, 120, 551-555.

6. Luo YG, Ren ZH, Ma H, Yu T, Wen BC. Stability of periodic motion the rotor-bearing system with coupling faults of crack and rub-impact. Journal of Mechanical Science and Technology, 2007, 21( 6), 860-864.

7. Zheng GT. Vibration of a rotor system with a switching crack and detection of the crack. Journal of Engineering for Gas Turbine, 1998, 120, 149-154.

8. Wen BC, Wu XH, Ding Q, et al. Theory and experiment of nonlinear dynamics for rotating machinery with faults. Science Press, Being, 2004, 112-124.

9. Wan FY, Xu YQ, Li ST. Vibration analysis of cracked rotor sliding bearing system with rotor-stator rubbing by harmonic wavelet transform. Journal of Sound and Vibration, 2004, 271, 507-518.

10. Darpe AK. A novel way to detect transverse surface crack in a rotating shaft. Journal of Sound and Vibration, 2007, 305, 151-171.

11. Dimarogonas AD, Paipetis SA. Analytical methods in rotor dynamics. Applied Science Publishers, London, 1983.

12. Loya JA, Rubio L, Fernández-Sáez J. Natural frequencies for bending vibrations of Timoshenko cracked beams, Journal of Sound and Vibration, 2006, 290(3-5), 640-653.

13. Zachwieja J, Peszynski K. Service life of rotors under mechanical and thermal stress, 22nd International Conference Engineering Mechanics, Svratka, Czech Republic, 9-12 May, 2016.

14. Cuevas Arteaga C, Rodríguez JA, Clemente CM, Segura JA, Urquiza G, Hamzaoui YEl. Estimation of useful life in turbines blades with cracks in corrosive environment, Engineering Failure Analysis, 2013, 35, 576-589.

15. Poursaeidi E, Bakhtiari H. Fatigue crack growth simulation in a first stage of compressor blade, Engineering Failure Analysis, 2014, 45, 314-325.

16. Diken H, Alnefaie K. Effect of unbalanced rotor whirl on blade vibrations, Journal of Sound and Vibration, 2011, 330, 3498-3506.

\section{Received 2018-08-29}

Accepted 2018-11-15

Available online 2018-11-22

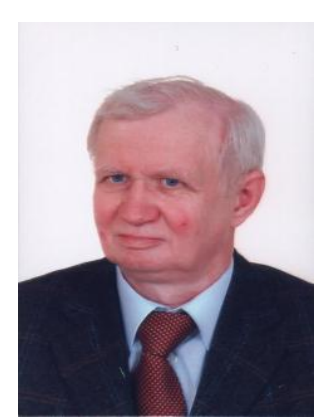

dr hab. inż. Janusz ZACHWIEJA is the Professor in the Department of Applied Mechanics at the University of Technology and Life Sciences in Bydgoszcz (Poland). His scientific interests include dynamics of mechanical systems and fluid mechanics. 